\title{
Land Management in the Sokoto Caliphate: Lessons for Contemporary Nigeria
}

\author{
Bayero A.S. Muhammad \\ Department of Business Administration, Usmanu Danfodiyo University, \\ Sokoto, Nigeria
}

\begin{abstract}
This paper contributes to the quest for a suitable land management model for Nigeria through an examination of the contributions of . the Sokoto triumvirate - Uthman Dandodio, Abdullahi Danfodio and Muhammad Bello (the most prominent of the leaders of the caliphate) to land management by reviewing their works and the writings, of contemporary scholars on the issue to 'provide a synthetic exposition of the caliphate's land management system. It discusses the caliphate's land tenure and land development system, preservation and reservation of land resources, management of water resources, pastures and farming as well as urban land planning and administration. The paper also evaluates the caliphate's land management policies in terms of their relevance and implications for contemporary land management.
\end{abstract}

\section{Introduction}

Proper land management is essential for economic growth of any society because of the vital role that land plays in peoples lives. .People cannot live without land because all activities are performed on land and they need land for production (whether manufacturing or agricultural), as well as residential purposes. Land is so important that, there is a saying that "whoever owns the land wields the power". The whole of history is characterized by the fight for land between clans, tribes and nations and the pattern of land tenure that each society adopts has a bearing on the efficiency and productivity of the people. In the conventional sense land has been viewed as a factor of production. This means that if land is costly, goods and services will be costly, and if land is cheap, goods and services will be cheap. Hence availability of land at reasonable costs is of great importance to the production process and consequently to the economy.

Improper land management has often been pointed out as the cause of persistent poverty of the underdeveloped countries because it allows access to land for productive purposes to be restricted and monopolized by a few landed class at the detriment of a large landless class. This causes high land values and leads to politicization of land grants by politicians who use it to gain votes. Those who hold this view think that the only way out is 
land reform, so that, land is made available at low cost to any citizen who needs it (Jacoby, 1971:19). Such reform has been attempted in Nigeria through the Nigerian Land Use Decree of 1978 but no significant results have been achieved so far either due to implementation problems or problems with the decree itself.

Following the failure of these conventional western-based land management systems to solve the problems of developing countries including Nigeria, it is believed that it is-time to look backwards to the land management systems in operation in developing countries prior to the advent of colonialism to devise land management systems suitable for our situations and thus more likely to achieve the desired results. One such systern that could provide possible solution to this problem is that in operation in the former Sokoto caliphate which once consisted of a land area of approximately one million square metres spanning across most of present day northern Nigeria and substantial parts of present day Cameroon and Niger Republics (Muhammad, 1998:55).

Prior to the establishment of the Sokoto caliphate, the cardinal principles of land management were that land belonged to all the people which may be held by individuals or jointly by families or Gandu with the family head who is normally the oldest man in the family regarded as the administrator of the land and responsible for its allocation to individuals (Mamman, 2000). Any land allocated to an individual in this way becomes the property of the individual throughout his lifetime but reverts back to the Gandu for reallocation to others after his death.

When the Sokoto caliphate was established, the leaders of the caliphate (the Sokoto jihad leaders) changed the land management system of the area from what it was to the Islamic system. The most important of the works of the jihadists on this issue is the work of Abdullahi Danfodio, entitled Ta'alim al-radi,Fi asbab al-Ikhtisas bi mawat al aradi, which has been translated into English by Zahradeen (1990) and Gwandu 1996). In this work and other works, the jihad leaders provided guidelines for proper planning, organization and control of land resources for its equitable utilization in line with the shari 'ah, where every man's right is protected and no one is denied the right to own a piece of land for lawful needs.

This paper contributes to the quest for a suitable land management model for Nigeria through an examination of the contributions of the Sokoto triumvirate - Uthman Danfodio, Abdullahi Danfodio and Muhammad Bello (the most prominent of the leaders of the caliphate) to land management by reviewing their works and the writings of contemporary scholars on the issue in order to provide a synthetic exposition of the caliphate's land management system. It discusses the caliphate's land tenure and land development system, preservation and reservation of land resources, management of water resources, pastures and farming as well as urban land planning and administration. The paper also 
evaluates the caliphate's land management policies in terms of their relevance and implications for contemporary land management. These are presented in the sections below.

\section{Ownership of Land (Land Tenure)}

For the purpose of gaining ownership of land, lands are divided into two classes. The first are ma 'mur lands, which are cultivable and can readily be put to use, and, thus, are desirable and have utilization costs. The second are mawat lands, which are referred to as dead lands which are uncultivable or that require substantial initial expenditure for development. ${ }^{1}$

In the Sokoto caliphate, the Imam can grant permanent or temporary ownership of land in the form of either right of ownership or right of occupancy to individuals. If permanent ownership is given, then the person to whom the land is granted has exclusive right over it and he can sell it or give it to another person and it can be inherited from him. This applies whether the land is situated near centers of population or far from them. However, the Imam cannot grant permanent ownership for ma 'mur lands designated as waqf (public endowments). Also, permanent ownership can only be obtained from the Imam, and all other ways of owning land confer only right of usufruct; thus, the land itself cannot'be sold.

The other way of gaining ownership of land is by cultivating or developing mawat land. The majority view given by the scholars is that owning a land in this way confers full rights of ownership to the developer (Gusau, 1991; Ayagere, 1997:360: and Gwandu, 1996:7)2. However, Abdullahi Danfodio reports that another view say? the developer only has right of usufruct. In-fact even in the case of lands given by the ruler, there are some scholars that feel that only right of usufruct are given and one cannot sell such land. In Diya al Siyasat, ${ }^{3}$ Abdullahi .Danfodio, citing authorities like Ibn Arafah, Abubakar Ibn Abdurrahman and Qasim al IqbaT in al Miiyar, concludes that land is held in trust for people by the authorities and can only allocate its usufruct and not the physical land and hence those allocated the land cannot sell it to others.

To sum up the land tenure system of the Sokoto caliphate, we feel Chafe's (1990:45-46) view aptly describes it. He says that every member of the community in the caliphate had a right of access to land and nobody is allowed to comer a piece of land and keep it uncultivated just for the purpose of alienating others. He cites Anwa ' $u$ Malutlahi, ${ }^{4}$ where Shehu emphasized the importance of agriculture and Bello who, in his urbanization policy, proposed that ribats (fortresses) should be made prosperous by assigning a plot of land to anybody seeking to develop it. 


\section{Land Development}

The land policy of the Sokoto caliphate was designed to stimulate productive use of land by stressing the primacy of man on the land policy for mawat lands, which are the lands from which the generality of the populace benefit, and hence, the most important in land policy. However, if one neglects a land that he had previously cultivated before, and another person comes to re-cultivate it, the ownership belongs to the second person. Abdullahi brings this view in la 'alim al Radi ${ }^{5}$ but cites a view by Ashab that says that the land belongs to the second cultivator only if the land is far from the centers of population. However, in order to avoid exploitation of this rule by unscrupulous elements, Abdullahi says that it is recommended that it should be applied only if a long period had elapsed before being redeveloped by the second developer.

If one discovers that another person is redeveloping a property that he had developed and feels it is unjust but he keeps silent, the property belongs to the second developer. If, however, he protests, he should be made to swear an oath that his failure to develop the property ; not that he is neglecting the land, after which he may be required to compensate the second developer at a rate which varies, depending on whether or not the second developer is aware that the land has been developed before or not. If the second cultivator is not aware that the land has been previously developed, face value of the development is to be paid to him. If he was aware, only the disposable value should be paid to him.

Discouragement of speculation and exploitation of mawat land are further highlighted by the leaders of the caliphate. For instance, Abdullahi Danfodio shows that, by majority view, building of fence round a piece of the land for the purpose of exclusion of others does not amount to development and, hence, cannot confer ownership rights on the person who does this. Likewise, land is not considered developed by simply grazing one's animals on it, or by sinking a well on it as water points for the animals. Abdullahi gives seven ways by which land could be considered developed: ${ }^{7}$

i. Drilling and channeling of springs on a piece of land meant for cultivation;

ii. Draining water from a flooded land;

iii. Erecting substantial building on a land;

iv. Substantial planting on a land;

vi. Clearing by cutting and burning trees on the land; and

vii. Breaking up boulders and stones on the land and then leveling it. ${ }^{7}$

This policy is effective because all these ways mentioned improve the fertility and utility of land, which is the way of improving the productivity of land. 
The Sokoto triumvirate leaders also commented on the issue of need for permission from the Imam in developing a piece of land. If a land is near the centers of population, then permission is needed in order to develop such lands. If, however, land is far away from towns and villages, no permission is required to develop it. Land is considered near if it is within the harim of the town or adjacent to it. The issue of harim is discussed in the next section.

If a person develops a virgin (mawat) land that is near the centers of population without the permission of the Imam, the Imam is at liberty to approve the development or disapprove of it and confiscate it for the common use of the people. If he disapproves of it, he should provide the land developer with an alternative plot or with compensation.

\section{Harims (Precincts)}

Related to the issue of land development is the issue of the precincts of a developed land. To ensure orderly and planned land development, the Jihad leaders elaborated on what constitutes the precincts of towns, houses, and orchards. This issue is important because it makes for neat and orderly development of land for agricultural, residential and commercial purposes, so that people have easy access to their properties and places to graze their animals.

Abdullahi Danfodio gave the harim of a town or village as land round the town or village where the inhabitants graze their animals and or get firewood, the distance of which must not exceed a day's journey to and from. It is illegal for anyone to develop such land as the land serves as a reserved space for its purpose. More will be discussed on reserved spaces in the next section. This type of harim was still evident some thirty years ago in Sokoto, but buildings and roads have now replaced most of such hurumi (the Hausa name for harim) and the harim is much farther from the town and not as large as recommended here.

The harim of a house which is surrounded by mawat land refers to those areas surrounding the house which serve as entrances, exits, seating place in front of the house, toilet, and rubbish dump. If, however, the house is surrounded by other people's property, then no one has exclusive right to the reserved space and every one can use the space in front of his house, provided that he does not cause harm to others.

For orchards, farm or gardens, the harim is the piece of land that provides access to it without causing harm to others. Where there is dispute, experts should be invited to arbitrate.

Abdullahi Danfodio ${ }^{8}$ urther provides for the harim of ponds, seas, rivers, etc. A summary is given in the Table below: 


\author{
Land Resource \\ Pond \\ Sea \\ Swamp \\ Well used for irrigation \\ House or valley located in ownerless land \\ $\mathrm{Road} /$ Foot path
}

\author{
Harim \\ Five cubits \\ One thousand cubits \\ Five hundred cubits \\ Twenty cubits \\ Twenty cubits \\ Seven cubits
}

The harim of a well sunk for watering animals and of a river used for the same purpose is that area that is enough to accommodate the herdsman and his herds. No specific area is mentioned in this case.

Buildings erected on public highways must be pulled down if they cause inconvenience to passers by. Even if they cause no inconvenience, they must be pulled down according to majority view in the Maliki Figh. However, it is pointed out that such roads refer to public roads. For private roads and roads which develop because of the collapse of the buildings of a house thereby providing unauthorized passage, the owner has right to block it or erect a building on it. If, however, one's building collapses and people turn the place into a path fpr a long time and the owner -does nothing, he loses ownership of the path. HoweVer Sheikh Abdullah! did not explain what constitutes a long tune. Also any path that develops on buildings demolished by the authorities becomes a public path.

\section{Al-Hima (Reserve)}

The Imam or his deputy can create a reserve other than a harim whereby the general public is prevented from grazing animals there and the piece of land is reserved for breeding particular animals, e.g. horses.

The Sokoto triumvirate identified four conditions necessary for the creation of a hima to be valid. ${ }^{10}$

(i) Only the Imam can establish it because of the Prophet's (SAW) saying that "the hima is only for God and His Messenger" and the Imam is the representative (vice-regentnt) of the Prophet,

(ii) It is needed for the welfare of the people of the state.

(iii) It should be a small area, i.e. an area surplus to the needs of the people, having no vegetation or building belonging to anyone, such as mawat land, dry riverbeds and mountaintops.

(iv) It should be used exclusively for animals such as horses and camels used for defence purposes, animals given to the state as alms and animals belonging to the poor.

The leaders of the Sokoto caliphate also gave examples of hima creation in Islamic history. The Prophet is reported to have made al-Naqi (a part of a place called al-Aqiq near Madina) into a harim for use by the horses of the Makkan immigrants in Medina (Muhajiruns). Its area was eight square 
miles. Abubakar al Siddiq also appointed Usama to oversee the hima at al-Rabhada, and Umar appointed Hunayya over the hima of al-Sarif for both the grazing of camels given as alms to the community and the livestock of the poor. Al-Rabhada was also increased in size by some caliphs after Umar.

\section{Water Resources}

The Sokoto triumvirate was also concerned with effective management of water resources and provided policy guidelines for using four types of water resources commonly found in society. Here also it was Abdullahi Danfodio's Tq 'alim al Radi that was used as a guide for the caliphate!'

The first water resource is free water located on free land either in the form of a river, a pond or a lake. All people have equal rights to use this water and no one should have exclusive rights over it.

The second is personal water that is owned by someone on a land owned by him. This belongs to the owner who can alienate others or sell it. However, one is encouraged to let people use it freely, but he should-not be compelled to do so except where people may die of thirst due to lack of water, in which case the owner of the water can be compelled (by force) to $i$ let them use it. Also if the neighbour of the owner of a water resource encounters a problem with his own water resources used for irrigation and his crops may wilt away, then the neighbour whose water resources, are functioning should allow his disposed neighbour free access to the water after using as much as he requires for himself as long as the neighbour is engaged in repairing his source of water supply. This shows a system where both individual and communal rights to resource utilization are provided for.

Third is rainwater. This belongs to everyone and the owner of the first land it reaches can use it, dam it until his land is flooded ankle deep (two cubits) and then allow it to flow to the next land.

The fourth is water of well sunk in the wild for watering animals. The person who made the well has priority over its use, but he must allow others to use the excess freely.

\section{Pastures}

Another aspect of land policy of the caliphate pertains to pastures for animal grazing. In Ta' alim al-Raldi, ${ }^{n}$ Sheikh Abdullahi provides that pasture that is not owned by the anyone is public pasture and should be freely available to all who wish to graze their animals there. But, if the pasture is on someone's land, then that person has priority over others There is difference of opinion on the legality of selling pasture or preventing others from using it. Citing al-Kharachi, Sheikh Abdullahi 
mentioned that, if one neglects to cultivate a piece of land because he does not need it, then he has no right to prevent grazing rights to others in that land. However, if his crops encircle the pastures and damage may occur to the crops in trying to gain access to the pasture, then one can prevent others from getting to it. Also if one preserves a piece of land for his livestock, he can prevent others from grazing their livestock there even sell the pasture, if he likes.

Abdullahi Danfodio also elaborated on how to deal with problems that occur between agricultural and pastoral people such as that between Hausa farmer and Fulani nomads. He provides that if livestock enter farmland and destroy crops, the owner of the livestock must compensate the owner of the crops. Citing Ibn al-Arabi's Ahkam, which was reporting the view of Malik Ibn Anas, Abdullahi wrote that animals that habitually destroy crops should be sold or transferred to a place without crops (Zahradeen, 1976:263).

\section{Fanning}

According to the Sokoto triumvirate, farming is the strongest and most rewarding of all occupations because its use extends beyond the farmer to other men, birds and insects ". The occupation requires knowledge, sense, kindness and Ikhlasi for it to be rewarding. The farmer should find out whether his ownership of the farm, the seeds he wishes to sow, his farming implement etc are halal because there is no reward without conformity to the sunnah and one's aim should not be to get output from his farm through whatever means are available. They identified some harim practices by farmer of the day such as exposure of ones al'aura i.e. sections of his thighs when farming.

Sultan Bello was reported to have a small garden in his house on which he personally used to work (Balogun , 1988:20). He also had a ranch at Segin Lemu and a farm at Garin Maidaji, the produce of which he used to maintain himself. It is believed that Bello was the first to introduce crops such as cassava, sugar cane, and many fruittrees to Sokoto. He also introduced shaduf, which is an irrigation method by means of cram and bucket. This shows his interest in technological progress in agriculture.

Abdullahi Danfodio made an important contribution with wider implication on fanning and fasting that caused a lot of controversies and a lot of uneasiness among jurists (Abdullahi, 1984:11). According to Sheikh Abdullahi, if crops become ripe on Ramadan and it is certain that the crops will perish if not quickly harvested, then it is not only lawful but also obligatory to harvest them and compensate the days of fasting missed afterwards. According to Sheikh, the basis for this ruling is that the poor have a lawful share in the farmer's produce and, if the crops are lost, the 
poor cannot be compensated for the loss; but fasting can be compensated by an equal number of days lost under the excuse of necessity.

\section{Land Planning and Administration}

The Sokoto triumvirate understood the need for proper town planning and the necessity of appointing people to look after land affairs. Thus, the granting of land for commercial, residential and agricultural purposes is to be governed by overriding public interest (Abubakar, 1991:54). Example is given in the case of one who owns gardens adjacent to the walls of a town and it is feared that the gardens may serve the interest of the enemies during war. The Imam can, in this case, force the proprietor of such gardens to hand them over to the state and compensation be paid to him. In fact, if the enemy invades, the garden can be destroyed or taken even without .compensation. If, however, the walls of the garden were built before those of the town and losses incurred are much, then compensation shall be paid even in this second situation.

As for land officials, they are exhorted to be careful in their jobs and avoid expropriation of the lands and farms of the people These verses from Usman Danfodio's Wallahi Wallahi ' $\sim^{1}$ capture this exhortations aptly:

Be wary of the issue of your lands know ye

Be wary of their farms know ye

Be wary of their riches know ye

There is poison in their farms know ye

Those who leave them follow us wallahi wallahi.

\section{Relevance of the Caliphate's Land Management System to Contemporary Nigeria.}

From the forgoing presentation, the following important observations on the relevance of the Sokoto caliphate's land management policies to contemporary Nigeria can be made:

The principle of primacy of man on the land operated in the caliphate, whereby the person who cultivates a virgin piece of land has primary rights of ownership over that piece of land, is likely to encourage people to develop such lands so as not to lose their rights of ownership to subsequent developers. They may even settle on those lands for effective supervision of activities. This policy is likely to increase productive land utilization and consequently output and is likely to be the reason that made the caliphate into a surplus producer of foods. This policy could be useful in contemporary land management in Nigeria. 
The policy of the Jihad leaders encouraged livestock rearing by making pasture easily available to all. Muhammad-Baba (1990: 120) asserts that the period following the establishment of the caliphate in 1804 was a period of pastoral ascendancy because the pastoralists (mostly Fulani) became integrated into the socio-economic system of the region and were no longer alienated. Unrestricted access to territories and utilization of pastures and watering points enabled pastoralism to become integrated in the agrarian structure and livestock production became part of the general agricultural production. Thus, pastoralism ascended in the Sokoto caliphate. The regions of the former Sokoto caliphate still remain major producers of livestock for themselves and net suppliers of the commodity to other nearby regions presently. By providing an organized system that accommodates the needs of both farmers and pastoralists as regards land use in the caliphate, the leaders of the caliphate solved the problem of conflict between them. This has relevance for contemporary Nigeria as this is a wide spread problem in the country nowadays. The method used in the Sokoto caliphate can provide a useful input in the development of a suitable land management model that addresses this problem.

That absolute ownership of land is possible under the Islamic land management model operated in the Sokoto caliphate gives it an edge over the pre-caliphate system in operation in the region. This is because the pre-caliphate system does not confer absolute ownership of land to allotees, which may discourage the allotee from erection of certain kinds of capital-intensive structure on the land as the land may revert back to the community after the death of the allotee. Absolute ownership possible in the land management model of the Sokoto caliphate also distinguishes it from contemporary Nigerian land management policy whereby land grants by government are leasehold in nature - usually for a period ninety-nine years. This has the same implication as the precaliphate system mentioned above in addition to subjecting such land grants to possible politicization when they become due for renewal. This aspect of the caliphate's land policy could form useful input into contemporary land management policy in the country and stimulate more productive use of land by land grantees due to the additional motivation that this policy provides in terms of security of ownership;

The Jihad leaders' land management policy also guards against land speculation and exploitation of the landless by a few landed class. This is because dead land cannot be fenced off for the purpose of alienating others or with the intention of creating artificial scarcity in land thereby creating value for and profiting from it. TMs/policy could be useful in stimulating productive use of land if/ adopted by underdeveloped countries like Nigeria. 
The land management system of the Sokoto triumvirate further highlights its goals of eradicating poverty and assisting them from unnecessary burdens in line with contemporary poverty alleviation goals. Thus, even where himas or reserved places are created, the animals of the poor are to be allowed to graze there. Another observation is on Abdullah! Danfodio's methodology in writing the Ta 'alim al Radi. He was not concerned with one particular view and, in many cases, he gives all views, including minority views on issues from all schools of thought i.e. Hanbali, Maliki, Abu Hanifa schools and Shafi'i schools and in most situations he does not advocate for any view but allows the adoption of any view. Ayagere (1971: 336) proposes that this may be because Sheikh Abdullahi Danfodio feels that sticking to one Mazhab (Muslim school of thought) is not important, or because his sources made similar citations, or simply a relaxation of rigidity or a move to assuage public opinion. Since this position is perfectly legal in Islam, Nigerian Muslim could well emulate it not only in management of land resources but also in other aspects of their lives where similar differences exist, in the interest of peaceful coexistence and progress.

The fact that Sultan Bello introduced irrigation by use of crum and bucket shows that he was an open-minded person who was receptive of new ideas and recognized the importance of technology in development and would have no doubt supported the technological farming devices of today to the extent that they increase production and ease the work of man, but not the extent that they make man redundant. This has important implication for present day Nigeria where labour is abundant and technology is largely imported. Thus, the benefits of labour intensive agriculture in terms of provision of employment, social welfare, conservation of foreign exchange and distributional equity need to be weighed against the benefits of capilat intensive (technologically based) agriculture in terms of economies of scale and greater agricultural output in order to arrive at an optimal mix that is suitable for our situation.

The issue of hima may not be necessary in contemporary societies because technological development has reduced the need for firewood as a use desertification and destruction of the ecosystem. Another important point that has bearing on contemporary societies is the issue of seven cubits of harim for a road within which people must not sit or stand. In many urban centers in countries like Nigeria, you find buildings which are very close to the road and you find petty traders and hawkers thronging public roads, hereby causing commotion, congestion and go slow which have adverse effect on productivity of people. If people can heed the teachings of Sheikh Abdullahi in this respect, it may go a long way to solving the problem 
Permitting the damning of rainwater for irrigation purposes in the caliphate's land policy shows that modern damming operations are sanctioned by the shari 'ah and also lends credence to claims by down stream dwellers that damming of water up stream may affect water availability in their lands. Thus, unnecessary damming of water not used for electricity generation to the detriment of others is unjustified in the light of this.

\section{Conclusion}

From the foregoing discussion, it is evident that the Sokoto caliphate had a well-articulated land management system, which provided for easy access to land by all and thus facilitated its effective and efficient utilization for the development of economic welfare of the citizens. Contemporary societies could do well to borrow from the caliphate's land policy in developing land policies for their people that accommodate the needs of their people and are thus not only acceptable, but also beneficial to them.

\section{Endnotes}

1. See Danfodio, A. (N.D.), Ta'alim al- Radi,'translated by M.S. Zahradeen, 1990, State and Society in the Sokoto Caliphate, A.M. Kani and K.A. Gandi (eds), Usman Danfodio University, Sokoto, p.203; and Danfodio, U. (1806), Bayan Wujub al-Hijra ala L'Ibad, edited and translated by F.H. El-Masri, 1978, Khartom University Press. Khartoum, Democratic Republic of Sudan., pp. cit. p. 131. See also Gusau (1991:45).

2. See also Ta'alim al Radi, ibid., p. 203.

3. See Danfodio A. (1820), Diya al-Siyasatwa Fatawa al-Nawazil, edited, translated and analyzed in English by S.U, Abdullahi, 1980 ( M.A. thesis, Department of Islamic Studies, Bayero University, Kano), pp.186- 187. See also Abdullahi, (1984: 11).

4. Danfodio, U. (1810), Anwa'u Malullah, ref. No. 139/1. A M. Kani's collection , Northern History Research, ABU. Zaria

5. Ta 'alim al-Radi, op.cit, p. 199. See also Gwandu (1996:40).

6. Ibid.

7. Ibid, p. 200 and p.5 respectively.

8. Ibid

9. A cubit is an old measure equivalent to the length of the arm from the below to the tip of the middle finger, which is about $18+2,1$ inches approximately. See Chambers English Dictionary.

10. Bayan Wjub al-Hijra, op. cit., p. 70 and Ta'alim al Radi, op., cit., p. 204. See also Gwandu (1996: 8).

11 Ta 'alim al-Radi, ibid., pp. 204 - 205. See also Gwandu (1996:9) 
12. Ibid.

13. See Abdullah! Danfodio's Ktiabun-Niyyati fll A 'malid Dunyawiyyati waDinniyyati, translated into Hausa by M.I. T/Mafara, 1992, Sidi Umaru Printing Press, Birnin Kebbi., pp. 27-29

14. Danfodio, U.(N.D.), Wallahi Wallahi, Hausa Version, N.D, (Department of Nigerian Language, Bayero College, Kano), p.2.

\section{References}

Abdullahi, S.U. (1984), On the Search for a Viable Political Culture; Reflections on the Political Thought of Shaikh Abdullahi Danfodio, (Commercial Printing Department, New Nigerian Newspapers Limited, Kaduna)

Abubukar, M.1991), "Contributions of Abdullahi Fodio to the Economic Thoughts of Islam", in S.A. Gusau (ed), Economic Thoughts of Seven Great Muslim Scholars, (Usman Danfodio University Press, Sokoto), pp. 50-57.

Ayegere, P.D. (1971), The Land Use Act: Administration and Policy Implications (Lagos: University of Lagos Press).

Balogun, S.U. (1988), "Economic Policy of the Sokoto Jihad Leaders". Hamdardlslamicus, Vol. XI, No. 1

Bello, M. (1990), Al- Gayth al-Wabi jl Sirat ai-Imam ail-Adi, edited and translated into English by O. Bello (Unpublished Ph. D. Thesis. School of Oriental and African Studies, University of London, London).

Chafe, K.S. (1990), "The Transformation of Socio-Political Policies of the Leaders of the Sokoto Caliphate", in A.M.Kani and K.A. Gandi (eds), State and Society in the Sokoto Caliphate (Usman Danfodio University, Sokoto), pp.31 - 62.

Gusau S.A. (1990), "Economic Ideas of Shehu Usman Danfodio”, in S.A. Gusau (ed), Economic Thoughts of Seven Great Muslim Scholars (Usman Danfodio University Press, Sokoto), pp. 40-49.

Gwandu, A.A. (1996) "Land Acquisition, Ownership and Use in Islam-Sheikh Abdullahi, M.L.A. and Mikailu, A.S. (eds), Islam and Knowledge Forum (Usman Danfodio University, Sokoto).

Jacoby, E.H. (1971), Man and Land (Andre Deutsch Limited, London)

Mamman, AB (2000), "Land Management in Nigeria", in Nigeria: A People United, A Future Assured, Vol.1, Ajaegbu H.I., Mathew - Daniels B.J. and Uya O.E. (eds.) (Calabar: Gabuma Publishing Company Ltd), pp. 97- 102.

Muhammad, B.A.S. (1998), "Economic Thought of the Sokoto Jihad Leaders" (Unpublished Ph.D.Thesis, Department of Economics, Usman Danfodio University, Sokoto). 
Muhammed Baba, T.A. (1990), "Pastoral Ascendancy in the Savannah: A Sociological Assessment of the 1804 Jihad on the Pastoral Fulbe", in State and Society in the Sokoto Caliphate, A.M. Kani and K.A. Gandi (eds.), (Usman Danfodio University, Sokoto), pp.104-125.

Yakubu, M.G. (1985), Land Law in Nigeria, (London: Macmillan Publishers Ltd.)

Zahradeen, M.S. (1976), “Abdullahi Ibn Fodio's Contribution to Fulani Jihad in Nineteenth Century Hausaland”(Ph.D Thesis, Islamic Studies, McGill University, Montreal, Canada). 